for the alternative Asterophyllites, which usually commends itself to Continental workers. The point may appear to be a small one, but any change of importance as regards nomenclature at the hands of the leading authority on the systematic study of Carboniferous plants in this country is worthy of note. Among the plants more fully described, on which new contributions to our knowledge are offered, we would particularly direct attention to the stems and cones of Calamites paleaceus, Stur., Selaginellites Gutbieri (Grepp.), Pinakodendron ohmanni, Weiss, and Sphenophyllum majus (Bronn). The memoir concludes with a discussion on the age and horizon of the Hainaut basin.

In conclusion, the Belgian palæobotanists may be congratulated on this noteworthy addition to the literature on their fossil floras, and on their good fortune in having secured such an authority as Dr. lidston to fulfil the task.

To the author we would add our congratulations on the successful completion of a volume which must have occupied his attention for many years past, and will always rank high in the annals of systematic palæobotany. We may also express the pious hope that some day our own British Carboniferous flora may receive an equally adequate treatment at his hands.

E. A. N. A.

\section{THE ELECTRICAL EXHIBITION AT} OLYMPIA.

THE important lesson to be learned from the Electrical Exhibition at Olympia is that rapid strides are being made towards a period of hygiene in our daily lives for which electricity will be wholly responsible. During the last six years a large number of electricity supply companies and corporation electricity departments have reduced their price for energy for heating, cooking, and similar domestic purposes to about one penny per unit, and manufacturers of cooking and heating apparatus have been developing this side of the industry with commendable rapidity. The large percentage of firms exhibiting and demonstrating domestic appliances, together with the comparative absence of heavy electrical machinery at Olympia, sufficiently indicates the aspect of electrical supply which is receiving the most attention. A factor in this important problem has been the development of cheaper wiring systems, a development purposely directed to securing the smaller consumer. In this direction also is to be noted the tendency towards the production of smaller and cheaper meters, cheaper service boxes, main switches, and other auxiliary apparatus.

Another factor which is helping to render the installation of electric light more economical, and therefore further within the reach of the smaller user, is that, owing to small devices, such as lamp-holders, switches and fuses being manufactured in large quantities, and practically to a few standard designs, the cost of these is now far less than it was a few years ago. This brings us to mention what is per= haps the most remarkable sign of the development of the electrical industry to the ordinary thoughtful observer outside the industry itself. Fifty years ago, or even less, electricity, except in so far as its applications to telegraphy were concerned, was practically an abstract science, fascinating no doubt on account of its potential developments, but scarcely a serious factor in engineering. Now, however, not only is electricity a most important agent in practically all branches of engineering, but the manufacture of elecNO. 2187 , VOL. 87$]$ trical plant and apparatus has assumed the proportions of a great industry. It is the commercial aspect of this industry which is so very clearly brought home to the visitor at the exhibition, especially in the case of those smaller pieces of electrical apparatus which form the bulk of the exhibits. The manufacture and sale of these has developed into an enormous trade, and one can see that the-exhibitors at Olympia are not only engineers and electricians, but are business men and traders, in the widest acceptance of these terms.

To return to the actual exhibits. It will be noticed that one of the most outstanding features of the exhibition is the improvement in electric lamps. Only a few years ago the metal filament lamp was an object of scientific interest, the difficulties of even squirting the filament not then having been overcome to the extent of producing a lamp with any considerable degree of capability to withstand rough usage. Some of the metal filament lamps shown now are exhibited under conditions designed to illustrate that they are as strong mechanically as the carbon filament lamps which they are rapidly superseding. Several manufacturers are now making filaments of drawn tungsten, and the clou of the exhibition, from the electrical engineer's point of view, is a 16-c.p. 220volt Osram lamp, which has a filament only o.o $5 \mathrm{~mm}$. drameter, and yet possesses wonderful mechanical strength. Other lamps are shown, fitted on two model tramcars, which are allowed to run down inclines and collide with one another. Before the moment of impact, the lamps are purposely switched off, as it is when the filaments are cold that they are more brittle; yet the lamps withstand this rough usage without any damage, and are again lighted automatically as they are propelled up the inclines to enable the operation to be repeated.

The standardisation to which we have alluded applies to a considerable extent to lamp shades and reflectors, and concurrently with this the old haphazard way of installing lighting systems is giving way to more precise methods. Shades and reflectors of the Holophane type, designed to effect even distribution of light, are exhibited as stock articles by several firms, and much information is available at the exhibition in this hitherto little considered detail of electric lighting. The most careful arts of the glassworker are now employed to give effect to the investigations of the student of optics in the production of diffusing globes and reflectors which, by conservation and redirection of the rays of light, prevent waste and give maximum effect in any desired direction.

The adaptability of electricity to artistic fittings is also well demonstrated in an exceedingly fine show of models to suit almost every style of architecture of the English and Dutch schools. There is also a display of some very dainty French crystal pendants, together with reproductions of the genuine old Dutch lighting fittings of the sixteenth and seventeenth centuries.

A new development that may be mentioned is in connection with the mercury-vapour lamp. A "light transforming reflector" is being introduced, made of a material which becomes fluorescent under the action of the light from the lamp, and increases the number of red rays; although this has not actually solved the problem of converting the light from the mercuryvapour lamp into a pure white light, it is at any rate a step in the desired direction.

The visitor who proposes only to spend a short time at the exhibition in which to form an idea of the numerous domestic applications of electricity to which we have alluded will find a large number of these concentrated in the "Electric Home." This is a 
suite of rooms consisting of drawing, dining, bed, and bath rooms, together with a kitchen and scullery, efficiently and beautifully lighted. In the kitchen demonstrations of electric cooking are being carried out, and are under the direction of a first-class cook. Electric laundry work is also shown.

\section{A COUNTRY IN THE MAKING. ${ }^{1}$}

THE Argentine Republic has recently celebrated the centenary of its existence as an independent State, and, in the national "stocktaking" which inevitably belongs to such an event, considerable attention has been given to education, as a result of which we have two large volumes of statistical records, and a third volume of monographs, on the various grades of educational work that come under the direction of the State.

Prior to its escape from Spanish control, such education as there was in the country was under clerical, and, for the most part, Jesuitical direction. In the ancient (Argentine) city of Cordova, the foundation of which by Peruvian Spaniards dates back to I573, the Jesuits established a high school (Colegia maxima) in r6ro, which Pope and King combined to raise to the dignity of a university very few years later. The university was for two hundred years the sole representative of higher studies. It was secularised in I80o, and a sister university was set up at Buenos Aires in $182 \mathrm{x}$ by the recently organised Government.

It is interesting to note how world-wide was the influence of Napoleonic ideas. There was then no Department of Public Instruction, and the new university was entrusted with the duty of educational administration in the city and district. After various experiments in constitution-making, however, the influence of the great republic of the north made itself felt, and in the federal form of government which was completely adopted in $x 860$, the duty of providing primary schools was put upon the local legislatures, and a central Ministry of Public Instruction was also formed. It was not, however, until Sarmiento's presidency (I868-73) that the country really woke up to its educational needs. Sarmiento had been an exile for some years, and during that time Chile had sent him to Europe and the United States to study educational systems. He had met Humboldt, Guizot, Cobden, and Horace Mann, and entered upon his presidential period full of great projects for the development of national education. His influence led to greatly-increased grants from the central exchequer to the provincial governments, and to the establishment of a great training college for teachers on the model of similar institutions in the United States.

The degree of progress which has been attained in the provision of primary schools, and the vast difficulties of the Government, are best illustrated by the comparative number of children between six and fourteen who could not read or write (illettrés) in $\mathrm{I} 895$ and in rooo. There were in the former year 57 per cent., and in the latter $32^{\circ} 6$ per cent. Education is compulsory between six and fourteen; we may suppose that the children in school do not learn to read within a year, and so reduce the $32^{\circ} 6$ to approximately 28 per cent. - not a bad result if we keep in mind the enormous territory and the sparseness of the population, immediately the precincts of the large towns are left behind. Uruguay is the only other South American State which comes approximately near to such a result; the number of illiterates rises to 80 per cent.

"Republique Argentine. Recensement général d'Éducation levé le 23 mai rogo." $\mathrm{Bv}$ Alhert $\mathrm{P}$. Martinez. Tome i, "Population Scolaire." Pp. xlii+448. Tome ii, "Statistique Scolaire." Pp. 1xxiii +344. Tome iii, "Monographies." Pp. ii+702. (Buenos Aires, rqто.)

$$
\text { NO. } 2 \text { I } 87 \text {, VOL. } 87]
$$

in Brazil and go per cent. in Venezuela. In spite of what has been accomplished in the sphere of primary education, the cost to the State is very small in comparison with what is paid for the higher schools and universities.

Most of the secondary schools are under the direct control of the Central Government. They follow a five-year course preparatory to the university. As is the case in Austria, it is worthy of note that psychology is a subject of instruction in the last school year. The schools in Buenos Aires are magnificently housed; their equipment is costly, and their staffs are ample. The five schools cost the city more than $100,000 l$. in 1908. But in the smaller towns things do not go so well. The subjects are appropriated to chairs (catedras), the holders of which must give at least three hours a week instruction. They are for the most part occupied by local professional men, whose main interests are not, of course, in the school. There are two State high schools for girls, in Buenos Aires and in La Plata, but the majority of girls are educated in conventual institutions. The Jesuitical seminaries also attract many of the sons of the wealthier classes.

There are now three universities in the country, a third having been founded by the State of La Plata in 1906. This last foundation follows the United States model, with a supervising president who brings unity into the system of government by more or less independent faculties such as obtains in Cordova and Buenos Aires. All the universities are handsomely provided with funds. In 1908, Cordova received 55,00ol., Buenos Aires 90,oool., and La Plata 86,oool. from the national exchequer. Nor is capital expense spared. The State has recently voted I,200,00ol. for various university buildings, including a new hospital for the medical school at Buenos Aires, and buildings at Cordova in celebration of the tercentary of its foundation. ${ }^{1}$

Vigorous life and a profound belief in education are obvious everywhere. Technical schools, a new public school on the English pattern, magnificent museums and libraries such as our great provincial cities may long vearn for in vain-all these are pointed to with legitimate pride. Here and there in the record one comes across interesting bits of heterodoxy, which bear witness to a healthy independence of view. "J'estime que 1'institution des Kindergarten est une véritable hérésie pédagogique et un crime de lèseenfance." This is startling, to say the least. Nevertheless, the volumes fill one with admiration for the pride and faith in the future of their country which animates their authors and the administrators whose work they record.

J. A. GreEN.

\section{DR. F. W. PAVY, F.R.S.}

$\mathrm{N}$ September I9 the death occurred of Dr. Frederick William Pavy, F.R.S., in his eightythird year. Dr. Pavy was born in Wiltshire in May, I829, and was educated at Merchant Taylors' School. He subsequently entered Guy's Hospital, where he had a distinguished career, and in the course of his graduation at the London University took the exhibition and gold medal in materia medica, the gold medal in medicine, and honours in other subjects. He became a doctor of medicine in $18_{53}$. He studied physiology in the laboratory of Claude Bernard, in Paris, and soon began that prolonged research into the relation of sugar to the animal economy, in reference to the causation and treatment of glycosuria and diabetes, which terminated only with his life.

${ }^{1} V$, article "Argentine Republic," Macmillan's Cyclopædia of Educa tion." 